International Journal of Applied Mathematics

Volume 34 No. $4 \quad 2021,795-802$

ISSN: 1311-1728 (printed version); ISSN: 1314-8060 (on-line version)

doi: http://dx.doi.org/10.12732/ijam.v34i4.14

\title{
HUMIDITY LEVEL ON COVID-19 WITH CONTROL STRATEGIES
}

\author{
Evren Hincal ${ }^{1,2}$, Bilgen Kaymakamzade ${ }^{1,2} \S$, \\ and Nezihal Gokbulut ${ }^{1,2}$ \\ ${ }^{1}$ Department of Mathematics, Near East University \\ 99138, TRNC, TURKEY \\ ${ }^{2}$ Mathematics Research Center, Near East University \\ 99138, TRNC, TURKEY
}

\begin{abstract}
Coronavirus spread through all the world in a short time. By November 2020, approximately 46,5 million people infected and more than 1,2 million people died because of this disease. The main objective of this paper is to answer the question that whether temperature has an effect on coronavirus or not. For that purpose, we divided countries into 2 groups according to the average temperatures to compare SARS-CoV-2 cases between the continents which have the average temperature greater than $30^{\circ} \mathrm{C}$ and less than $30^{\circ} \mathrm{C}$.

SARS-CoV-2 virus does not divided into subgroups in this paper. Only positive cases considered as a database. Data from 1 September 2020-27 October 2020 were obtained from WHO database.
\end{abstract}

AMS Subject Classification: 62P10, 92B10, 62G30

Key Words: SARS-CoV-2; temperature; humidity; ANOVA test

\section{Introduction}

A novel coronavirus (SARS-CoV-2) has started at the end of the December 2019 in Wuhan City, Hubei Province of China. Middle East Respiratory Syndrome Coronavirus (MERS-CoV) and Severe Acute Respiratory Syndrome (SARS$\mathrm{CoV}$ ) are two spaces of the coronavirus that belong to the Betacoronavirus

Received: March 27, 2021

(C) 2021 Academic Publications

${ }^{\S}$ Correspondence author 
genus that caused the SARS-CoV-2. These viruses can be spread from an animal (like bird, swine, cattle, horses, cats, bats etc.) to a person as well as it can be spread from person to person via coughs, sneezes, breathing, or through contact with infected people (see [3], [4], [6], [7], [10], [11], [13], [15], [16], [18]). Virus attacks to the respiratory system and has symptoms similar with influenza, respiratory syncytial infection, etc. (see [23]).

After Wuhan City, the outbreak of the SARS-CoV-2 spreads through all China in a short time and then other countries of the world such as Japan, Thailand, Malaysia, Spain, Italy, France, Turkey, Austria, Dominican Republic etc. The public transport and air travelling are the most potential way for the spread of SARS-CoV-2 globally (see [9], [14]). Therefore, the airlines of the most countries are closed in March 2020. The incubation period of the disease depends on people as between 2-14 days (see [12], [20]).

By November 2020, more than 674,771,447 tests were made in the world (see [10], [19]). According to WHO, 47,246,984 of people have been recorded with cases of Covid-19 and 1,209,962 people died because of the disease. Till recently (see [5], [21], [22]) there were no enough effective vaccines or treatments for the Covid-19 and the cases of Covid-19 have continued to increase.

There are some discussions about the spread of Covid-19 at the warm weather $\left(>30^{\circ} \mathrm{C}\right.$ ) and humidity (above $\left.10 \mathrm{~g} / \mathrm{m}^{3}\right)$ conditions. Some studies says that the spread of the virus in the countries with warm air condition is slower than the cold air conditions (see [1], [2]).

In this paper, we divided countries into 2 groups by means of continents according to the temperature and we compared SARS-CoV-2 cases between the countries which have the average temperature greater than $30^{\circ} \mathrm{C}$ and less than $30^{\circ} \mathrm{C}$. The first group captures the continents Australia and Asia while the other group contains the continent Europe. The first group includes the following countries: Australia, China, New Zeland, Singapore, South Korea, Taiwan, Thailand, and Vietnam. The second group contains Europe countries such as Austria, France, Germany, Italy, Spain, Turkey, and United Kingdom.

\section{Methods}

Data from 1 September 2020 to 27 October 2020 were obtained from WHO database. Number of incidence cases were calculated from the countries in the continents stated above. We have considered 5,690,510 cases. The countries were divided into 2 groups according to the average temperatures from the beginning of September 2020 until the end of October 2020. These groups are 
continents with the temperature less than $30^{\circ} \mathrm{C}$ and the continents with the temperature greater than $30^{\circ} \mathrm{C}$.

Analysis of Variance (ANOVA) is a powerful technique that can be used to show the difference between two or more means or components, by way of significance tests. In this study, ANOVA tests were applied in order to compare Covid-19 cases between the countries which have the average temperature greater than 30 and less than 30. Sum of squares between these two groups calculated by

$$
S S B=\sum_{j=1}^{k}\left(\bar{X}_{j}-\bar{X}\right)^{2},
$$

where $\bar{X}=$ overall sample mean and $\bar{X}_{j}=$ sample mean of the $j^{\text {th }}$ group, and $k=$ the number of independent comparison groups [8].

Descriptive statistics were calculated. Mean differences per 100,000 cases among the Covid-19 cases data for each of the groups were compared using the ANOVA test $(p<0.05)$. Mean squares are calculated by the following formula

$$
M S B=\frac{S S B}{d f_{b}},
$$

where $d f_{b}=n-k$ and $n=$ the total number of samples in a population [8].

The ANOVA test only tells whether there is a significant difference between groups or not; it does not give the reasons for the difference. Tukey's Honestly Significant Difference (Tukey's HSD) Test is a post hoc test and it used to decide the source of differences between groups that is obtained in ANOVA Test. The ANOVA test with the post hoc Tukey HSD test revealed the significant differences between groups for average temperature, relative humidity, absolute humidity, and altitude. It compares the means of groups. The formula of the test is given as follows:

$$
q_{t u k e y}=\frac{\left|\bar{X}_{1}-\bar{X}_{2}\right|}{S E_{A N O V A}},
$$

where $S E=$ standard error obtained from ANOVA [17].

The statistical analysis was performed using SPSS software (version 24.0.1, SPSS, Chicago, Ill). Results of univariate analysis and ANOVA have shown $95 \%$ confidence intervals $(\mathrm{CI})$ and 2 sided p-values. They are presented in Table 1 and Table 2. 
Table 1: 95\% Confidence Intervals(CI) of Factors.

\begin{tabular}{lrr} 
Factor & Median & $95 \%$ CI \\
\hline Number of Cases & 322 & $198-1678$ \\
Case Count(per 100.000 population) & 98 & $21-323$ \\
Average Temperature $1(30<)$ & 32 & $23.6-43.7$ \\
Average Temperature $2(30>)$ & 9 & $2.12-19.2$ \\
Relative Humidity & 72 & $32.6-80.1$ \\
Absolute Humidity & 5.4 & $2.1-20.9$ \\
Altitude(per 200 m) & 76.9 & $15.6-542.9$ \\
Latitude(per 200 degrees) & 32.2 & $20.1-44.5$ \\
Sanitizing & 27 & $84.4 \%$ \\
Quarantine & 29 & $90.6 \%$ \\
Closure of Schools and Universities & 27 & $84.4 \%$ \\
Closure of Borders & 28 & $87.5 \%$
\end{tabular}

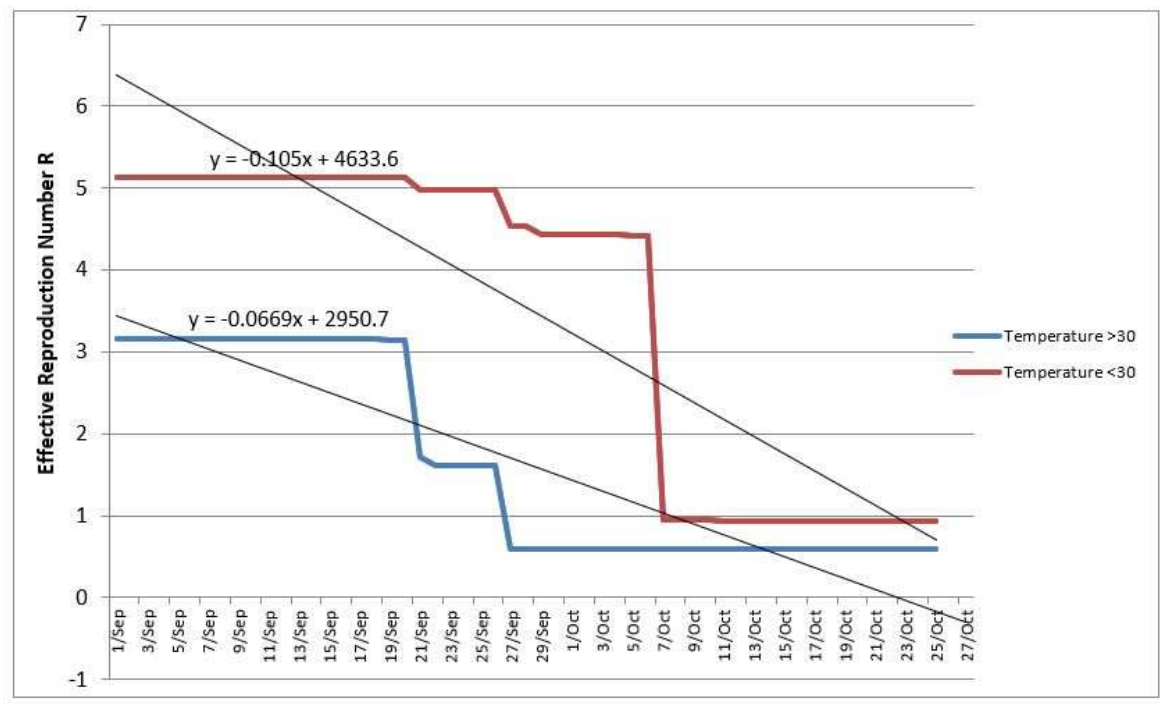

Figure 1: $R$ values are larger in the countries with the temperature $<30^{\circ} \mathrm{C}$.

\section{Results}

In this paper different continents with 5,484,611 cases were analyzed. The median SARS-CoV-2 cases per 100,000 inhabitants for 15 countries was 56 . In 
Table 2: 2 sided p-values of Factors.

\begin{tabular}{lrr} 
Factor & Median & p-values \\
\hline Number of Cases & 322 & \\
Case Count(per 100.000 population) & 98 & \\
Average Temperature $1(30<)$ & 32 & $<0.03278$ \\
Average Temperature $2(30>)$ & 9 & \\
Relative Humidity & 72 & $<0.03898$ \\
Absolute Humidity & 5.4 & $<0.02569$ \\
Altitude(per 200 m) & 76.9 & $<0.04329$ \\
Latitude(per 200 degrees) & 32.2 & 0.065 \\
Sanitizing & 27 & $<0.001$ \\
Quarantine & 29 & 0.00001 \\
Closure of Schools and Universities & 27 & $<0.001$ \\
Closure of Borders & 28 & $<0.00001$
\end{tabular}

our study, we investigated the relationship between the total number of cases and temperature, relative humidity, absolute humidity, altitude, and latitude based on the SARS-CoV-2 cases data until 27 November 2020. In accordance with this purpose, we compared the countries with the temperature less than $30^{\circ} \mathrm{C}$ with the selected European countries. The median temperature for these countries is $9^{\circ} \mathrm{C}(95 \% \mathrm{CI}, 2.12-19.2)$. On the other hand, countries having temperatures greater than $30^{\circ} \mathrm{C}$ such as Australia, Saudi Arabia, etc. (selected Australian and Asian countries) have the median temperature $32^{\circ} \mathrm{C}$. The relative humidity was $72 \%(95 \%, 32.6-89.1)$ and the median absolute humidity $5.4 \mathrm{~g} / \mathrm{m}^{3}(95 \%, 2.1-9.9)$ (see Table 1$)$. The temperature and absolute humidity have strongly relation in terms of with the square of latitude. However, relative humidity does not have any relation with the temperature. The graphs in Figure 1 could reflect one that those countries with the highest temperature (temperature $>30^{\circ} \mathrm{C}$ ) have lower effective reproduction number. Moreover, linear regression analysis $(R>0.80$ for both graphs) shows that the higher temperature countries have more rapid decrease in the Covid-19 cases.

\section{Discussions and conclusions}

As a result of this investigation, it was found that there is a significant differences between two groups of countries in terms of temperature, relative and absolute humidity, latitude and altitude and the transmission of SARS-CoV-2 
virus. Moreover, it was also found that effective reproductive numbers which can be seen in Figure 1, also difference in these countries. For further study we recommend to study this subject with dynamical modelling. Moreover, we could consider to apply control strategies such as optimal control or adaptive control in order to control humidity in the close areas. This is possible because first we could apply the optimal control in order to achieve the optimality and after that adaptive control for cost-effectiveness. This will help us to reduce the spread of coronavirus. Beside this machine learning or artificial intelligence both could be applied for controlling humidity. This is very important point and the doctors and microbiologists should take this point into account very seriously and in details.

\section{References}

[1] Accuweather: Study on new coronavirus says warmer weather may slow COVID-19 spread, and cooler weather may accelerate it. Accuweather, 2020 (https://www.accuweather.com/en/health-wellness/study-on-newcoronavirus-says-warmer-weather-may-slow-covid-19-spread-and-coolerweather-may-accelerate-it/707177).

[2] BBC: Will warm weather really kill off Covid-19? Geneva: BBC, 2020 (https://www.bbc.com/future/article/20200323-coronaviruswill-hot-weather-kill-covid-19).

[3] C. Huang, W. Yeming, X. Li, et al., Clinical features of patients infected with 2019 novel coronavirus in Wuhan, China, The Lancet, 395, No 10223 (2020), 497-506.

[4] Centers for Disease Control and Prevention: Coronavirus Disease 2019 (COVID-2019), 2020

(https://www.cdc.gov/coronavirus/2019-ncov/about/transmission.html).

[5] European Centre for Disease Prevention and Control: An agency of the European Union, Situation update worldwide, as of 21 April 2020. ECDP, 2020

(https://www.ecdc.europa.eu/en/geographical-distribution-2019-ncovcases).

[6] European Centre for Disease Prevention and Control: Coronavirus disease 2019 (COVID-19) in the EU/EEA and the UK eighth update, 2020 
(https://www.ecdc.europa.eu/sites/default/files/documents/c ovid-19rapid-risk-assessment-coronavirus-disease-2019-eighth-update-8-april2020.pdf).

[7] European Center Disease Prevention and Control: Novel coronavirus disease 2019 (COVID-19) pandemic: increased transmission in the EU/EEA and the UK sixth update, 2020 (https://www.ecdc.europa.eu/sites/default/files/documents/R RAsixth-update-Outbreak-of-novel-coronavirus-disease-2019-COVID-19.pdf).

[8] Hypothesis Testing-Analysis of Variance (ANOVA), (https://sphweb.bumc.bu.edu/otlt/MPH-Modules/BS/BS704_Hypothesis Testing-ANOVA/BS704_HypothesisTesting-Anova_print.html\#::text= Specifically $\% 2 \mathrm{C} \% 20 \mathrm{MSB} \% 3 \mathrm{DSSB} \% 2 \quad \mathrm{~F}(\mathrm{k}$, the $\% 20$ ratio\%20of $\% 20 \mathrm{MSB} \% 2$ FMSE).

[9] I.I. Bogoch, A. Watts, A. Thomas-Bachli, et al., Pneumonia of unknown aetiology in Wuhan, China: potential for international spread via commercial air travel, Journal of Travel Medicine, 27, No 2 (2020), \# taaa008.

[10] Our World in Data: Coronavirus (COVID-19) Testing, 2020 (https://ourworldindata.org/covid-testing).

[11] P.C.Y. Woo, S.K.P. Lau, C.S.F. Lam, et al., Discovery of seven novel Mammalian and avian coronaviruses in the genus deltacoronavirus supports bat coronaviruses as the gene source of alphacoronavirus and betacoronavirus and avian coronaviruses as the gene source of gammacoronavirus and deltacoronavirus, Journal of Medical Virology, 86, No 7 (2012), 3995-4008.

[12] S.A. Lauer, K.H. Grantz, Q. Bi, et al., The incubation period of Coronavirus disease 2019 (COVID-19.) From Publicly Reported Confirmed Cases: Estimation and Application, Annals of Internal Medicine, 172, No 9 (2020), 577-582.

[13] Science News: How the new coronavirus stacks up against SARS and MERS, 2020

(https://www.sciencenews.org/article/how-new-wuhan-coronavirusstacks-up-against-sars-mers).

[14] S. Zhao, Z. Zhuang, J. Ran, et al., The association between domestic train transportation and novel coronavirus (2019-nCoV) outbreak in China from 2019 to 2020: A data-driven correlational report, Travel Medicine and Infectious Disease, 33 (2020). 
[15] W.G. Carlos, C.S.D. Cruz, B. Cao, et al., Novel Wuhan (2019-nCoV) coronavirus, American Journal of Respiratory and Critical Care Medicine, 201, No 4 (2020).

[16] W. Ji, W. Wang, X. Zhao, et al., Cross-species transmission of the newly identified coronavirus 2019-nCov, Journal of Medical Virology, 92, No 4 (2020), 433-440.

[17] Wikipedia: Tukey's range test, 2020

(https://en.wikipedia.org/wiki/Tukey\%27s_range_test).

[18] World Health Organization: Coronavirus disease (COVID-19) advice for the public. Geneva: World Health Organization, 2020 (https://www.who.int/emergencies/diseases/novel-coronavirus2019/advice-for-public).

[19] World Health Organization: Coronavirus disease 2019 (COVID19). Situation report 71. Geneva: World Health Organization, 2020 (https://www.who.int/docs/default-source/coronaviruse/situationreports/20200331-sitrep-71-covid-19.pdf?sfvrsn=4360e92b_4).

[20] World Health Organization: Coronavirus disease 2019 (COVID19). Situation report 73. Geneva: World Health Organization, 2020 (https://www.who.int/docs/default-source/coronaviruse/situationreports/20200402-sitrep-73-covid-19.pdf?sfvrsn=5ae25bc7_2).

[21] World Health Organization: Coronavirus disease 2019 (COVID19). Situation report 81. Geneva: World Health Organization, 2020 (https://www.who.int/docs/default-source/coronaviruse/situationreports/20200410-sitrep-81-covid-19.pdf?sfvrsn=ca96eb84_2).

[22] World Health Organization: Novel Coronavirus (2019-nCoV). Situation report 1. Geneva: World Health Organization, 2020 (https://www.who.int/docs/default-source/coronaviruse/situationreports/20200121-sitrep-1-2019-ncov.pdf?sfvrsn=20a99c10_4).

[23] Y.C. Wu, C.S. Chen, and Y.J. Chan, The outbreak of COVID-19: An overview, Journal of the Chinese Medical Association, 83, No 3 (2020), 217-220. 